\title{
Enerji Etkin Bina Tasarımında Güneş Enerjisinden Pasif Yararlanma: Karataş Açık Ceza Evi Tekstil Atölyesi Projesi
}

\author{
Mustafa YEĞİN*1 \\ ${ }^{1}$ Çukurova Üniversitesi, Mimarlık Fakültesi, Mimarlık Bölümü, Adana
}

Geliş tarihi: 05.09.2019

Kabul tarihi: 30.09 .2019

$\ddot{\mathbf{O} z}$

Bu çalıșmada Karataş Kadın Açık Ceza Evi Tekstil atölyesi projesi tanıtılmaktadır. Yazar tarafından Haziran 2017 tarihinde Tekstil Atölyesi projesinin tasarımına başlanmış Aralık 2017'de tamamlanarak Karataş Kadın Açık Ceza İnfaz Kurumu Müdürlüğü’ne teslim edilmiştir. Çalışmada, projeye ilişskin tasarım süreci, tasarımda öne çıkan unsurlar, ergonomik faktörler, mekan kullanımları, alansal büyüklükler ve pasif tasarım ilkeleri ile elde edilen mekan kalitesi sunulmaya çalışılmıştır.

Anahtar kelimeler; Tekstil atölyesi mimari projesi, Cezaevi tekstil atölyeleri, Atölye bina programı, İş çevresi tasarımı, Adana

\section{Passive Solar Energy Utilization in Energy Efficient Building Design: Karataş Open Prison Textile Workshop Project}

\begin{abstract}
In this study, Karataş Women's Open Prison Textile workshop project was introduced. June December 2017, the design of the textile workshop project was started by the author and completed in December 2017 and handed over to the Directorate of Karataş Women Open Penitentiary Institution. In the study, the design process related to the project, prominent elements in the design, ergonomic factors, space uses, space sizes and passive design principles and the quality of the obtained space were tried to be presented.
\end{abstract}

Keywords: Textile workshop architectural project, Prison textile workshops, Workshop building program, Business environment design, Adana

*Sorumlu yazar (Corresponding author): Mustafa YEĞìN, myegin@cu.edu.tr 


\section{GíRiș}

Genel olarak, enerjinin etkin kullanımı, kalite ve konfor koşullarından, istenilen performans düzeyinden ödün verilmeksizin, hizmet elde etmekte daha az miktarda enerji kullanılmasıdır. Bir tasarım anlayışı olarak 'Enerji Etkin Tasarım Yaklaşımları' disiplinler arası çalışmalarda önemli bir konumdadir.

Yapılaşma faaliyetleri bir binanın inşa sürecini de içinde barındıran yapının yaşam döngüsünü (inşa, kullanım, yıkım) kapsayan faaliyetler bütünüdür. $\mathrm{Bu}$ faaliyetler içinde enerji tüketimin önemli bir bölümü, yapının tüketici tarafından kullanılırken bina içi konfor koşullarının (aydınlatma, iklimlendirme, havalandırma) oluşturulması ve korunmasıdır. Bu koşulları sağlayan ve denetleyen cihazların büyük bir kısmı fosil yakıtları kullanarak çalışmaktadır.

İnşaat sektörü dünya genelinde toplam enerji tüketiminde öncüdür ve sorumludur. İmar faaliyetleri her yıl küresel olarak kullanılan enerjinin \%40'ını tüketmektedir [1].

\section{YÖNTEM}

Yazarın tasarım sorumlusu olarak görevlendirildiği işlevsel ve ergonomik atölye projesi tasarımı, 'Yapılarda Performansı Attırmak İçin Yeni Metotların Modellenerek Geliştirilmesi' Ar-Ge projesi kapsaminda imar durumuna uygun iklimsellik ve ergonomik koşullar dikkate alınarak hazırlanmıştır.

Enerji etkin tasarım prensipleri bağlamında yatay sirkülasyonlar, atölye çalışma ve ofis yönetim odaları, depolar, 1slak hacimler, kapı ve pencere genişlikleri vb. tasarlanmış olup sonradan yapılacak emsallerine örnek teşkil etmesi amaçlanmıştır.

Bina ihtiyaç programı ve ergonomik konfor düzeyleri de dikkate alınarak tekstil atölyesi tasarımı ve uygulama projesi tamamlanmıştır. Tasarlanan binanın çizimleri ve modelleri üzerinden değerlendirmeler yapılarak, güneşlenme verileri için 'Dialux Programı' kullanılmıştır. Programa koordinat verileri girilerek yapı modellenmiş, yapılan modelleme üzerinden de belirli tarihler için gün 1 şığı analizleri program yardımıyla hesaplanarak doğal aydınlatma performansı sunulmuştur.

Rüzgar etkisi ve yapı ile etkileşimi şematik olarak değerlendirilerek sonuçlar elde edilmiştir. Rüzgar etkisinin tespitinde etkin rüzgar yönü ve hava hareketleri birer parametre olarak ele alınmış, yap1 içerisinde havanın açıklıklara göre hareketleri ve pasif tasarım ilkelerinin yapının performansı üzerindeki etkileri sunulmuştur.

\subsection{Enerji Etkin Bina Tasarımı}

Enerji etkin bina tasarımı ile aşağıdaki ilkeler amaçlanmıştır.

- Enerji korunumunun binada yükseltilmesi ile gereksiz 1sı kazanç ve kayıplarının önlenmesi,

- Aktif ve pasif iklimlendirmenin tasarımda kullanılması,

- İklim dengesizlikleri, çevresel kirlenme ve çevreyle ilgili bozulmaların engellenmesi,

- Çevreyle dost verimli ve yenilenebilir enerji kaynaklarının bina tasarımında kullanılması sağlanmıştır.

Enerji etkin bina tasarımı sürecinde etkili olan parametreler; bina aralıkları, binanın yönlendirilişi binanın konumu, bina kabuğu, bina formu ve doğal havalandırma düzeni olarak gruplandırılabilir.

$\mathrm{Bu}$ parametrelerden yararlanılarak binaların aktif ve pasif sistemler aracılığıyla enerji etkin olarak planlanması ve tasarımı mümkündür.

Türkiye, yenilenebilir enerji kullanımı için çok uygun bir ülkedir; örneğin güneş kuşağ1 üzerinde bulunmakta ve 2651,5 saat güneşlenmektedir bu da $1344,5 \mathrm{kWh} / \mathrm{m}^{2}$ güneş enerjisine karşılık gelir [2].

Pasif tasarım ilkeleri iş atölyesi tasarımında, tasarımcıların ve yönlendiricilerin, fiziksel çevre verilerini temel alarak; enerji korunumunu, geri dönüşümünü sağlamayı hedefleyen tasarım problemlerine ürettikleri çözümler bütünüdür. Bina 
tasarımına yönelik tasarım ilkeleri ve planlama süreci gerektirir.

Çizelge 1. Coğrafi bölgelere göre güneş 1şınımı dağılımı [2]

\begin{tabular}{|l|c|c|}
\hline $\begin{array}{l}\text { Coğrafi } \\
\text { Bölgeler }\end{array}$ & $\begin{array}{c}\text { Yillık Ortalama } \\
\text { Güneş Işınım } \\
\text { Şiddeti }\left(\mathrm{kWh} / \mathrm{m}^{2}\right)\end{array}$ & $\begin{array}{c}\text { Yillık Ortalama } \\
\text { Güneşlenme } \\
\text { Süreleri (Saat) }\end{array}$ \\
\hline $\begin{array}{l}\text { Güney } \\
\text { Doğu } \\
\text { Anadolu } \\
\text { Bölgesi }\end{array}$ & 1491,2 & 3015,8 \\
\hline $\begin{array}{l}\text { Akdeniz } \\
\text { Bölgesi }\end{array}$ & 1452,7 & 2923,2 \\
\hline $\begin{array}{l}\text { İç Anadolu } \\
\text { Bölgesi }\end{array}$ & 1432,6 & 2711,5 \\
\hline Ege Bölgesi & 1406,6 & 2726,1 \\
\hline $\begin{array}{l}\text { Doğu } \\
\text { Anadolu } \\
\text { Bölgesi }\end{array}$ & 1398,4 & 2692,5 \\
\hline $\begin{array}{l}\text { Marmara } \\
\text { Bölgesi }\end{array}$ & 1144,2 & 2525,7 \\
\hline $\begin{array}{l}\text { Karadeniz } \\
\text { Bölgesi }\end{array}$ & 1086,3 & 1965,9 \\
\hline
\end{tabular}

\section{KADIN AÇIK CEZA INFAZ KURUMLARINDA ÜRETIM FAALIYETLERI}

Açık ceza infaz kurumlarındaki üretim faaliyetleri kurumda kadrolu olarak görev yapan atölye şefleri tarafından yönlendirilmekte, ayrıca bu kurumlarda gerek görüldüğü takdirde serbest işçi statüsünde de eleman istihdam edilmektedir. Kadrolu personel aynı zamanda hükümlülerin bir meslek ve sanat öğrenmesini de sağlamaktadır. İş esası üzerine kurulmuş bulunan açık ceza infaz kurumlarında amaç üretime yöneliktir. $\mathrm{Bu}$ nedenle bu kurumlarda iş atölyeleri bulunmakta ve hükümlüler bu atölyelerde çalıştırılmaktadır. Atıl durumdaki hükümlü iş gücü, üretime kanalize edilmekte ve aynı zamanda tahliye sonrası bu hükümlülerin bir meslek ve sanat öğrenmeleri de sağlanmaktadır [3].

Cezaevleri, suç işleyen kişilerin toplum yaşamından kopmadan eğitilerek, topluma kazandırılması yolunda çalışan kurumlardır [4].
CGTİHK (Ceza ve Güvenlik Tedbirlerinin İnfazı Hakkında Kanun) Haziran 2005'te yürürlüğe girmiştir. $\mathrm{Bu}$ kanuna göre; Açık ceza infaz kurumları, hükümlülerin çalıştırılmalarına, meslek edindirilmelerine ve iyileştirilmelerine öncelik verilen, diş güvenlik görevlisi bulunmayan, güvenlik bakımından kurum görevlilerinin gözetim ve denetimi ile yetinilen kurumlardır. Açık cezaevindeki hükümlülerin bir işte çalışmaları zorunludur. Emekleri karşılığ prim alırlar. İaşe bedelleri kendilerinin kazançlarından tahsil olunduktan sonra geriye kalan tasarrufları tahliyelerinde kendilerine, vefatlarında mirasçılarına ödenir [5].

13/12/2004 tarihli ve 5275 sayılı Ceza ve Güvenlik Tedbirlerinin İnfazı Hakkında Kanunun 121 inci maddesi hükümlerine göre ve yine çıkarılan tüzüğün 3. maddesine göre ceza infaz kurumları içerisinde olması gerekli birimler tanımlanmıştır. $\mathrm{Bu}$ birimler, kapalı, yüksek güvenlikli kapalı, kadın kapalı, çocuk kapalı, gençlik kapalı, açık ceza infaz kurumları ile gözlem ve sinıflandırma merkezleri ve çocuk eğitim evlerinden oluşmaktadır [6].

Ceza infaz kurumlarındaki hükümlülerin var olan mesleklerini korumak veya meslek öğretmek amacıyla 1997 yılında 4301 sayılı Ceza İnfaz Kurumları ile Tutukevleri İşyurtları Kurumuna İlişkin Bazı Mali Hükümlerin Düzenlenmesi Hakkında Kanun'la işyurtları kurumu kurulmuştur. Anılan kanuna göre 'işyurdu' kavramı; hükümlü ve tutuklulara bir meslek ve sanat öğretmek veya meslek ve sanatlarını koruyup geliştirmek suretiyle üretilen ekonomik değerleri pazarlamak için ceza infaz kurumları ile tutukevleri bünyesinde oluşturulan atölye, tesis ve benzeri üniteleri ifade etmektedir. İş yurtlarının misyonu, hükümlü ve tutukluların işyurdu faaliyetlerine katılımını sağlamak onları topluma yeniden kazandırma, onlara meslek edindirmek ya da var olan mesleklerini geliştirmektir.

\section{1. İşyurtları Kurumunun Tekstil Üretim Faaliyetleri}

Ceza İnfaz Kurumları ile Tutukevleri İşyurtları Kurumu bünyesinde, hükümlülere bir meslek veya 
sanat öğretmek, meslek ve sanatlarını koruyup geliştirmek amaçları ile tekstil alanında 302 adet iş yurdu müdürlüğü mevcuttur. Tekstil alanında, kalıpçı, makineci, ara elemanı gibi tekstil sektörünün ihtiyaç duyduğu eleman yetiştirilmeye çalışılmaktadır. Ceza infaz kurumlarında tekstil, ayakkab1, deri, konfeksiyon ve terzi gibi alanlarda faaliyet sürdürülmektedir.

Bu kapsamda tekstil alanında, makineci, kalıpçı, ara elemanı gibi tekstil sektörünün ihtiyacı olan nitelikli eleman ihtiyacı karşılanmaktadır. Hareket Ekonomisi Prensipleri doğrultusunda öncelikli olarak verime doğrudan etkisi olması sebebi ile ekipman boyut ve büyüklükleri belirlenmiştir. Genel duruş ve görev değerlendirmesi çalışma alanında her eylem ve aktivite için ele alınmıştır.

Tekstil atölyesinde enerji tasarrufu, konfor temini, yönetim esnekliği gibi çağdaş organizasyonların bulunmasına önem verilmiştir. ÇSGB'nın İSG normlarına uygun olarak aydinlatma, havalandırma, yangın tesisatları ve kurulumları ile tavan ve zemin döşeme/kaplama malzemeleri belirlenmiştir.

\section{FİİKSEL ÇEVRE KONTROLÜ}

Fiziksel çevre; doğal ve yapay çevre olmak üzere ikiye ayrılır. Doğal çevre bünyesinde; iklim, coğrafya/topoğrafya, güneş 1şınımı/gün 1şı̆̆ 1 , rüzgar, bitki örtüsü, sıcaklık, nem verilerini barındırır.

Yapay çevre ise; komşu binalar/yüzeyler, gölgelenme/engeller, şehirleşme/altyapı, yerleşim/ konum/yönlenme verilerini barındırır.

\subsection{Fiziksel Çevre Kontrolünde Pasif Tasarım Parametreleri}

\subsubsection{Yapının Konumu}

Konum, iklimlendirme, güneşlenme ve hava temizliği ile alakalı verilere taban oluşturan bir parametredir.
Yapı Akdeniz bölgesinde Adana ili, Karataş İlçesinde yer almaktadır. Akdeniz bölgesi Türkiye'nin ortalama güneş süresi en yüksek ikinci bölgedir. Adana Bölgesi Şekil 1 ve 2'de gösterildiği gibi sıcak nemli iklim bölgesindedir.

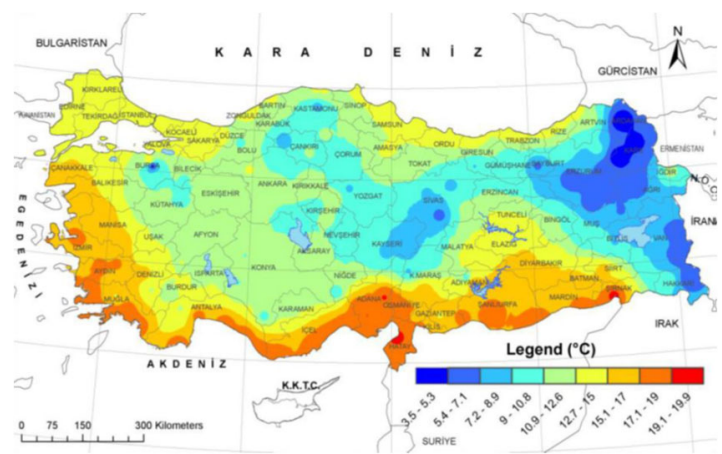

Şekil 1. Türkiye sıcaklık haritası [7]

\subsection{2. Çevredeki Yapılar}

Çevre yapılar ile yapı arasındaki mesafe ve yükseklik farkı, rüzgar ve güneş 1şınımı verilerini etkileyebilmektedir.

Yakın cevrede az katlı düşük yoğunluklu yapılar yer almaktadır. Binanın konumlanacağı alan Adana İli, Karataş İlçesi'nde ceza evi yerleşkesinde bulunmaktadır.

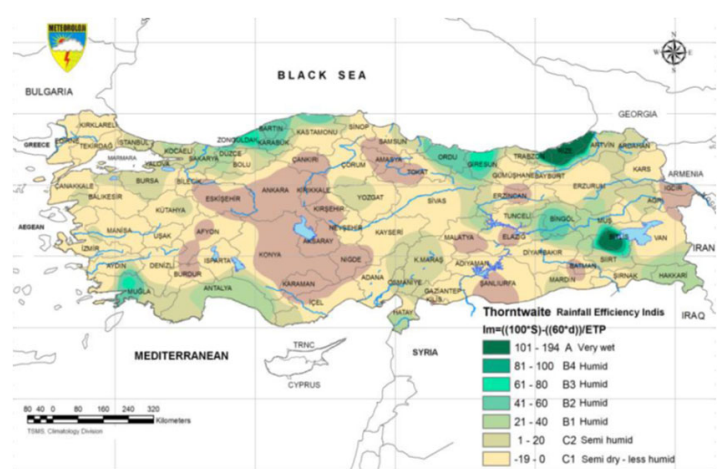

Şekil 2. Türkiye nemlilik haritası [7]

Yerleşke içinde yer alan diğer yapılarla da ilişkilendirilen atölye binası yüksek duvarlarla çevrili kampus alanı içindedir. Peyzaj projesiyle de rezerv yapılanma ve iş atölyesi bina alanları gelecekte yapılmak üzere önerilmiştir. 


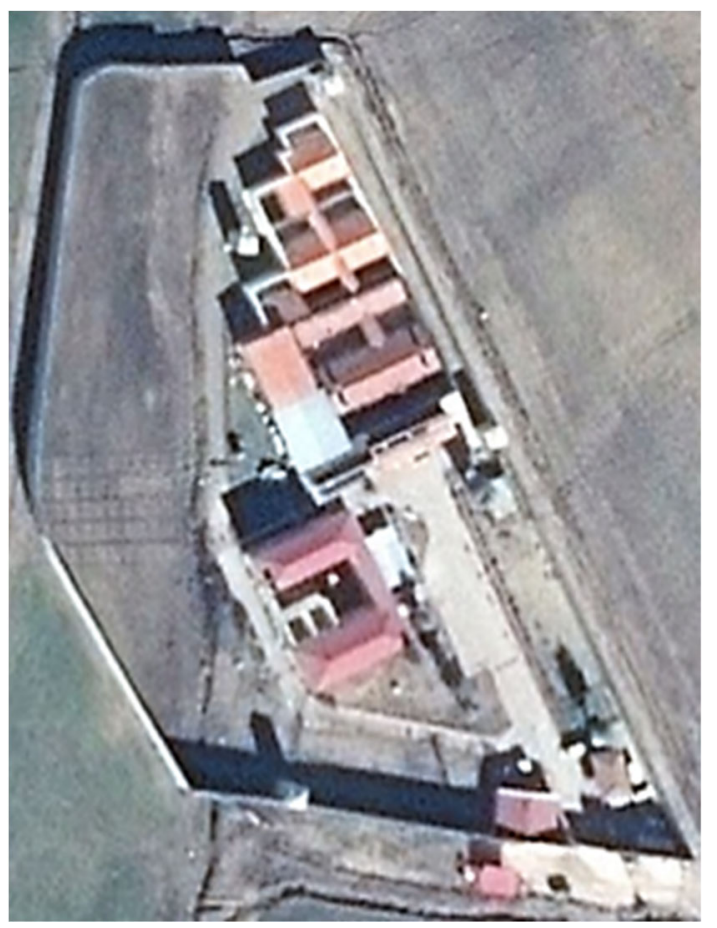

Şekil 3. Kadın Açık Ceza Evi vaziyet planı 2019 tarihli hava fotoğrafı Google Earth

\subsubsection{Yönlenme}

Hakim rüzgar yönü yönlendirici olmuştur. Güney, güney batı yönü yazın serinletici rüzgara sahiptir. Kışın, kuzey- kuzey doğudan esen soğuk rüzgar binaları olumsuz etkilemektedir. Dolayısıyla yapının ana cephesi güney olarak seçilmiştir.

$\mathrm{Bu}$ yönelim ile doğudan gelecek olan güneş 1şınlarının etkisi azaltılarak güneyden gelecek olan 1ş1k ile gün içerisinde güneşten maksimum fayda sağlanarak yapıdaki iç mekanların aydınlık kalması hedeflenmektedir. Atölye yapılarında (metabolik hız $1 \mathrm{~m} / \mathrm{s}$ giyinme katsayıs ise 0,4 olarak ele alınmıştır) yapılan analizlerde (Şekil 6) 1s1l konforun 25 santigrat derece olduğu sonucuna ulaşılmıştır

Atölye inşaat alanı toplam $592 \mathrm{~m}^{2}$ dir. Yapının toplam yüksekliği 3,75 m'dir. Nemden ve yüksek sıcaklıklardan kaçınmak ilk hedef olarak belirlenmiştir.

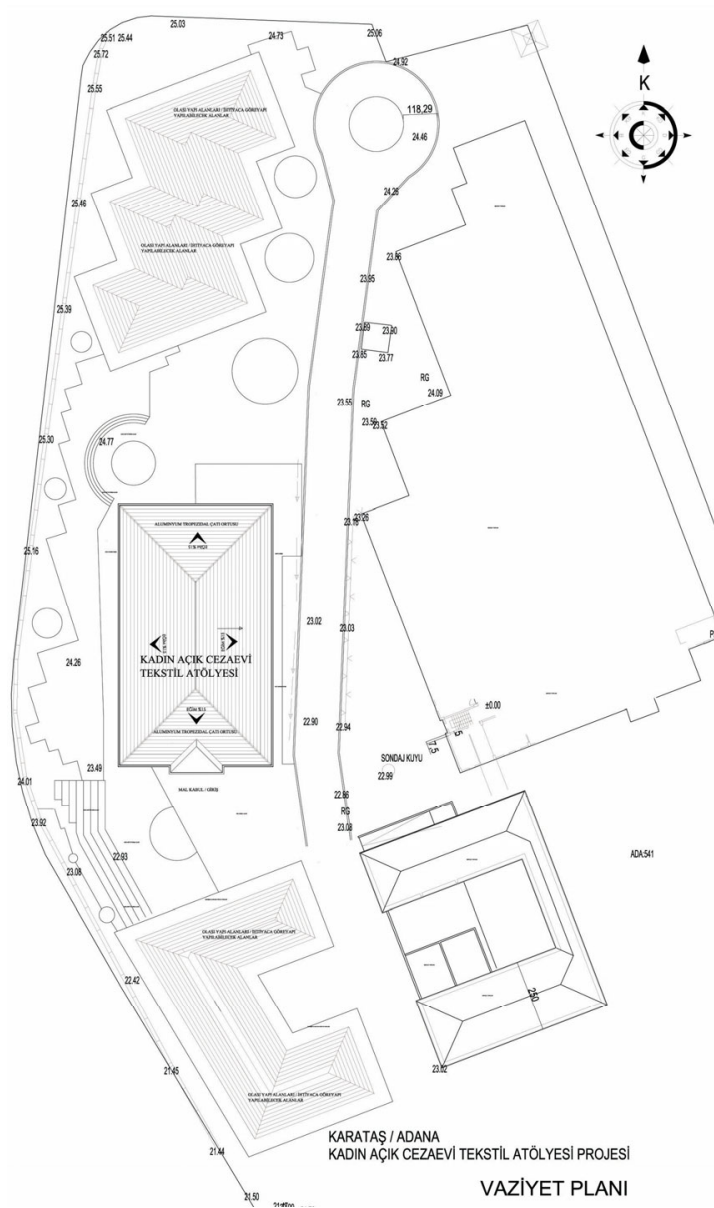

Şekil 4. Atölye çevre düzenlemesi ve vaziyet planı

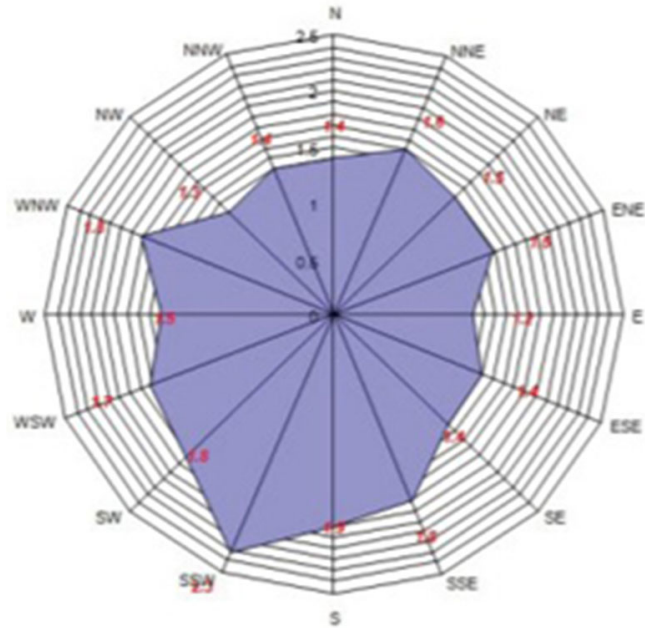

Şekil 5. Adana Bölgesi etkin rüzgar yönü [8] 

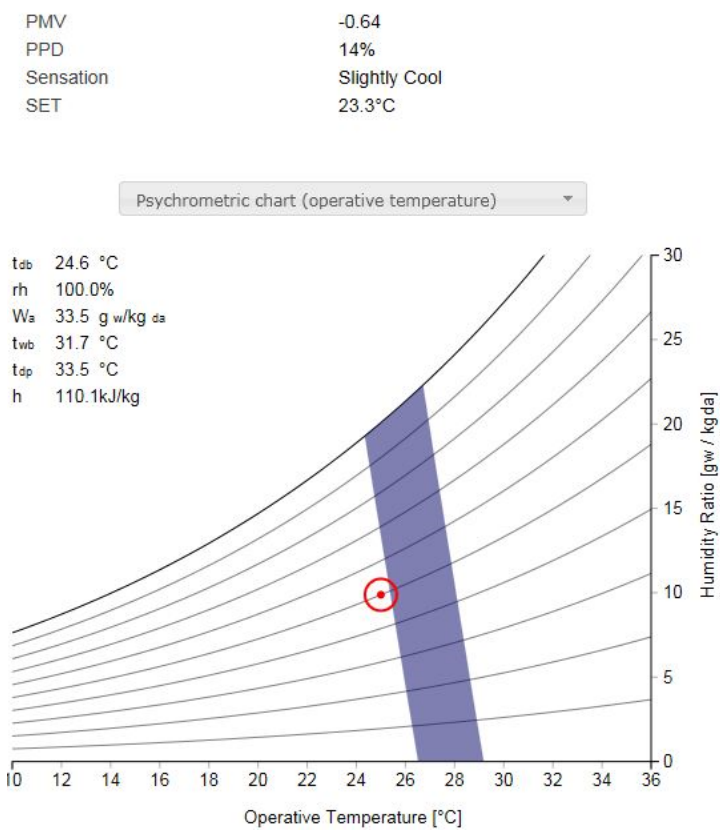

Şekil 6. Binada ısıl konfor aralığı [9]

Bölgede yaz aylarında ortalama sicaklık otuz derecenin üstündedir. Dolayısıyla etkin rüzgar (Şekil 5) yapının içerisine alınarak, hava sirkülasyonu sağlanmakta, iç mekanlarda nemin ve aşırı 1sınmanın önüne geçilerek, 1sıl konforun sağlanması, yapının soğutulması için gerekli olan enerjinin azaltılması hedeflenmektedir.

\subsubsection{Cephe Açıklıkları}

Çizelge 2. Cephe açıklıkları yüzdeleri

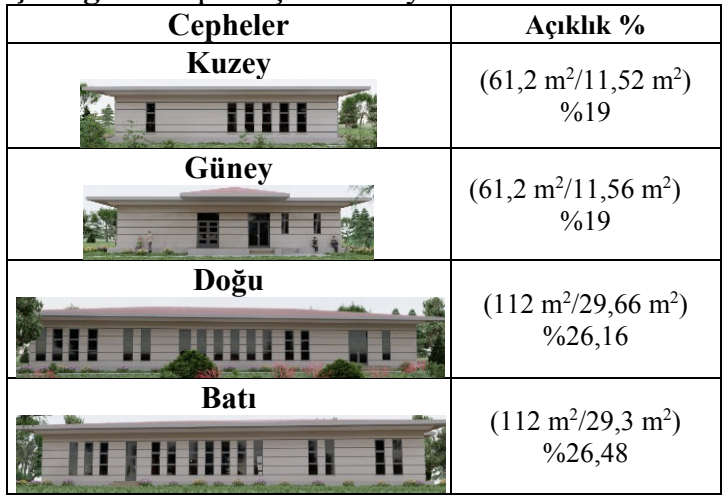

Yapıda bulunan açıklıklar tasarlanırken bina içerisindeki hava dolanımı ve güneş 1şınımı göz önünde bulundurulur, yapıda ısıl ve görsel konfor sağlamak hedeflenmektedir. Yapıda batı ve doğu cephesindeki açıklık oranları yüksek tutulmuştur, bununla birlikte gün içerisinde güneş 1şı̆̆ından ve hakim rüzgardan maksimum fayda elde edilmesi hedeflenmiştir. Batı cephesi açıklıkları ise akşam güneşinden ve hakim rüzgardan faydalanmak için yüksek tutulmuştur (Şekil 10).

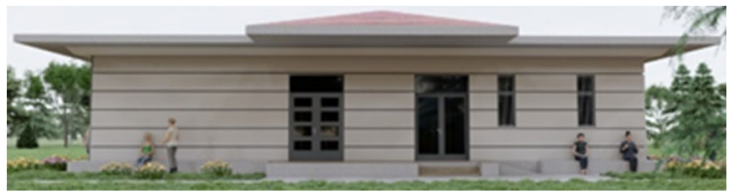

Şekil 7. Güney cephesi

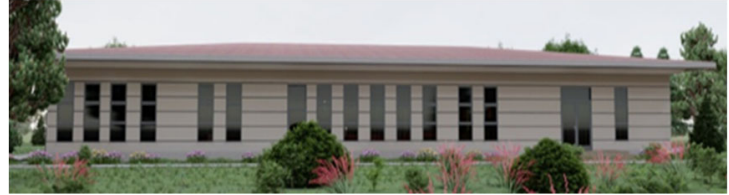

Şekil 8. Doğu cephesi

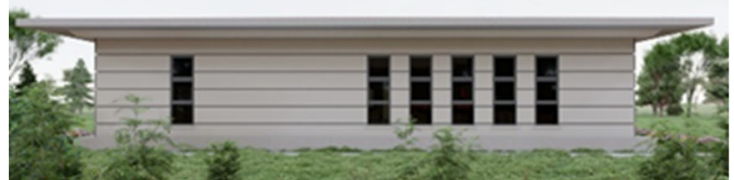

Şekil 9. Kuzey cephesi

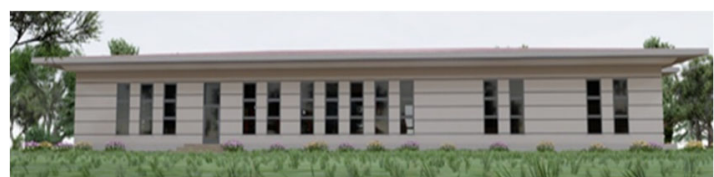

Şekil 10. Batı cephesi

Kuzey cephesinde bulunan açılıklar hava sirkülasyonunu sağlamak için oluşturulmuştur. Açıklık oranları yüzde olarak Çizelge 2'de yer almaktadır.

\subsection{Görsel Konfor}

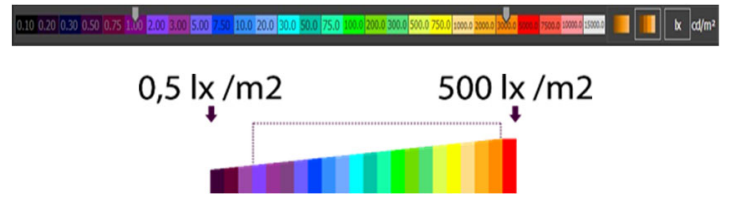

Şekil 11. Görsel konfor aralığ1 
Dialux programı kullanılarak iç mekanlardaki gün 1şığ1 miktarları gösterilmiştir. Cephelerde kullanılan açıklıklarla karanlık bölgelerin oluşması önlenip 1şık iç mekanlara ve çalışma ortamlarına düzenli bir şekilde ulaştırılmıştır.

Görsel konfor aralığı Şekil 11'de belirtildiği sınırlar arasındadır. Belirtilen aralığın altında kalan mekanlar 1şıklandırmaya, üstünde kalan mekanlar ise parlaklık önleyici mat yüzeylere veya cephelerinde güneş kırıcılara gereksinim duyar.

Atölye çalışma alanlarında sürekli 1şık alarak gündüz aydınlanma için gerekli olan enerji ihtiyacı minimuma indirilmiştir. Parlama güneş 1şığının yoğun miktarda iç mekanda bulunması ile yüzeylerin okunamaz hale gelmesi durumudur aynı zamanda yoğun 1şığa direkt maruz kalan göz retinalarında aşınmalar ve göz duvarında hasarlara sebep olmaktadır. Çalışma ortamları bu kriterler dikkate alınarak düzenlenmiştir.

\subsection{Atölye Çalışma Ortamı Gün Işığı Analizleri}

Personelin verimi, motivasyonu ve göz sağlığı için sağlıklı ve doğru bir ofis ve çalışma ortamı aydınlatması önerilmelidir. Yapılan çalışmalarda en iyi 1şığın beyaz 1şık, gün 1şığ1 olduğu bilinmektedir. Beyaz 1şıktan maksimum düzeyde yararlanmak esas olmalıdır. Tasarımda gün 1şığından yararlanmak adına yeterince pencere konulmaya çalışılmıştır. Aydınlatmada daha çok floresan veya kompakt floresanlı armatürler tercih edilmiştir. Çalışma ortamında eşit aydınlatma düzeyi sağlanmasına dikkat edilmiştir. Yeterli aydınlatma ortamı ile verimli ve kaliteli çalışmanın gerçekleşebilmesi mümkündür. Çalışılan nesnenin renkleri, şekilleri ve ayrıntıları yeterli aydinlatmaya sahip ortam da net olarak seçilebilmektedir.

Tekstil ve konfeksiyon atölyelerinde kumaş/aksesuar veya ürün üzerinde özellikle kalite kontrol işlemi sırasında çok dikkat gerektiren işlemler yapılmaktadır. Gerekli olan aydınlık düzeyi yapılan imalatın ve çalışılan parçaların özelliklerine göre değişiklik göstermektedir.
Çizelge 3. Çeşitli görsel görevler için önerilen en düșük aydınlık düzeyi [10]

\begin{tabular}{|c|c|c|}
\hline $\begin{array}{l}\text { Görsel } \\
\text { Görev } \\
\text { Sinıfları }\end{array}$ & $\begin{array}{l}\text { Aydınlık } \\
\text { Düzeyi } \\
\text { (Lüks) }\end{array}$ & Örnekler \\
\hline $\begin{array}{l}\text { Çok kaba } \\
\text { işler }\end{array}$ & $20-100$ & $\begin{array}{l}\text { Çok az trafiği olan koridorlarda } \\
\text { güvenle hareket etmek için }\end{array}$ \\
\hline $\begin{array}{l}\text { Kaba } \\
\text { işler }\end{array}$ & 150 & $\begin{array}{l}\text { Kaba, ara sıra yapılan tezgah ve } \\
\text { makine işleri; kaba yoklama ve } \\
\text { stokların sayımı, ağır } \\
\text { makinelerin montajları }\end{array}$ \\
\hline $\begin{array}{l}\text { Oldukça } \\
\text { hassas } \\
\text { işler }\end{array}$ & 300 & $\begin{array}{l}\text { Orta derecede hassas tezgah ve } \\
\text { makine işleri; montaj ve } \\
\text { yoklamalar; okuma kayit ve } \\
\text { dosyalama gibi büro işleri. }\end{array}$ \\
\hline $\begin{array}{l}\text { Hassas } \\
\text { işler }\end{array}$ & 700 & $\begin{array}{l}\text { Hassas tezgah ve makine işleri, } \\
\text { montaj ve yoklamalar; çok } \\
\text { hassas boyama ve } \\
\text { püskürtmeler, koyu renkli } \\
\text { malların dikişi. }\end{array}$ \\
\hline $\begin{array}{l}\text { Çok } \\
\text { hassas } \\
\text { işler }\end{array}$ & 1500 & $\begin{array}{l}\text { Hassas mekanizmaların montaj } \\
\text { ve yoklamaları, takım ve kalıp } \\
\text { yapımı; ölçme; hassas taşlama } \\
\text { işleri. }\end{array}$ \\
\hline $\begin{array}{l}\text { Olağan } \\
\text { dışı zor } \\
\text { önemli } \\
\text { işler }\end{array}$ & $\begin{array}{l}3000- \\
\text { yukarisı }\end{array}$ & Saat yapımı ve onarımı \\
\hline
\end{tabular}

Çizelge 3'de yapılacak imalatın tanımına göre gerekli minimum aydınlatma şiddetleri verilmiştir. Tekstil sektöründe aydınlık düzeyi konusunda yapılacak işlerle ilişkili literatürde verilen değerler doğrultusunda Çizelge 4'de yer alan gruplama yapılmıştır [9].

Çizelge 4. Bir konfeksiyon işletmesinin üretim bölümlerinde olması gereken minimum aydınlık düzeyi [11]

\begin{tabular}{|l|c|}
\hline Departmanlar & $\begin{array}{l}\text { En Düşük Aydınlık } \\
\text { Düzeyi (Lüks) }\end{array}$ \\
\hline Numune & 300 \\
\hline Kesimhane & 300 \\
\hline Dikimhane & 500 \\
\hline Kalite kontrol & 900 \\
\hline Model Kalıp & 500 \\
\hline Depolar & 300 \\
\hline Katlama Poşet & 300 \\
\hline Ütü & 500 \\
\hline Tasnif & 500 \\
\hline
\end{tabular}


Çizelge 5. 31 Mart, 30 Haziran ve 31 Aralık tarihlerinde gün ıșığı analizi

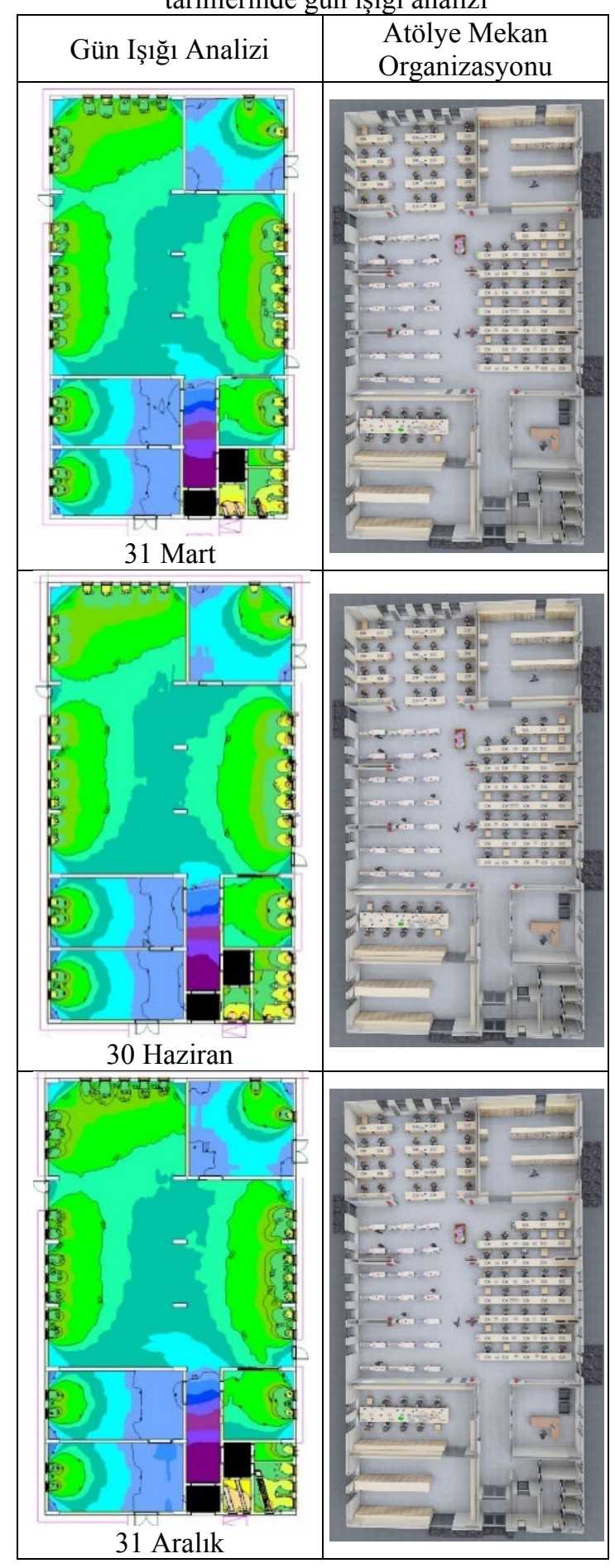

Başarılı bir aydınlatma sisteminde birçok faktör dikkate alınmalıdır. Işı̆̆ın miktarı, yönü, yayılması, rengi ve aydınlatılan yüzeyin yapısı önemlidir.

Açık renkli yüzeyler üzerine düşen 1şığın \%90'nını yansitırken koyu gri ve kirli yüzeyler ancak \%10'nunu yansitabilmektedir. Aydınlatma kolayca görmeyi sağlayacak derecede yüksek olmalıdır.

Doğrudan pasif güneş sistemlerinde bina, güneş 1şınlarını alarak doğrudan iç mekanlara aktaracak şekilde tasarlanmaktadır.

Tasarım doğrultusunda güneş 1şınları ara bir sisteme gerek olmadan cam yüzeylerden geçerek mekana alınmakta ve depolanması sağlanmaktadır. Çizelge 5'de 31 Mart, 30 Haziran ve 31 Aralık tarihlerinde gün ışığ 1 analizi yapılarak mekanların gün 1şı̆̆ını kullana bilme performansları gösterilmiş̧ir.

Atölye mekanlarında günışığ 1 aydınlık düzeyleri değişik gün ve saatler için Dialux programı ile belirlenmiştir. Doğrudan pasif güneş sistemlerinde pencereler, duvar yüzeyi veya çatıdan geçen ışınımla iç mekan yüzeyinde depolanan enerjinin sera etkisi oluşturarak binanın bir enerji toplayıcı gibi kullanılması amaçlanmaktadır. $\mathrm{Bu}$ sistem, binanın kendisi dışında ek bir sistem ve maliyet gerektirmemesi nedeniyle yaygın olarak tercih edilmektedir. Sistemde, ısının toplandığı ve depolandığı pencere açıklıkları ile duvar ve çatı yüzeylerinin güneş enerjisi girdisinin yeterli ve 1s1 kaybının en düşük olacak şekilde yönlendirilmesi ve boyutlandırılması önem kazanmıştır. Tüm mekanların çalışma ve üretim alanlarında gerekli aydınlık düzeyini sağladığı Çizelge 5 'de görülmektedir.

\subsection{Isll Konfor}

Binanın yer aldığ Adana İli, Akdeniz iklim özelliklerini taşır. Yazları sıcak ve kurak, kışları 1lık ve yağışlıdır. Yağışlar \%51 kış mevsiminde, $\% 26$ ilkbaharda, $\% 18$ sonbaharda, $\% 5$ yazın düşer. Bina tasarlanırken özellikle iklim ile uyumlu olmasına dikkat edilmiştir. Güneşlenme süresinin fazla olması ve sıcaklıkların özellikle yaz aylarında 
uzun olması nedeniyle cam yüzeylerde Solar LowE camlar yani güneş 1şığı geçirme katsayısı düşük olan camlar tüm cephede önerilmiştir. Low-E cam kullanımı kış aylarında içeride oluşan ısının pencereden tekrar içeriye yansıtılmasını, yaz aylarında ise güneşten gelen kızılötesi 1s1 yayımının dışarıda kalarak iç mekanın serin kalmasını sağlayarak pencerelerin verimini önemli ölçüde artıracağı değerlendirilmektedir. Bina cephesinde 1S1 yalıtımı yapılarak 1Sı köprülerinin oluşumu önlenmiş ve isı kontrolü ve enerji tasarrufu sağlanmıştır. Low-E kaplamalı cam yüzeylerin geniş olması içeriye giren 1sı miktarını önemli ölçüde azaltırken, doğal aydınlatmayı engellememektedir. Tüm mekanlar doğal aydınlatma konforuna sahiptir ve bu aydınlatma yüklerini önemli ölçüde azaltmaktadır. Bina hakim rüzgar yönünde yerleştirilmiş olup tüm mekanlarda doğal havalandırma yapılabilmektedir. Enerji etkin bir yapı tasarımında iç ve dış mekanı birbirinden ayıran yapı elemanlarından oluşan ve enerjinin korunmasında, ısıl konforun sağlanmasında önemli rol oynayan yapı kabuğunun kullanımı tercih edilmiştir. Güneybatıdan alınan rüzgar yapı içinde dağılmaktadır. Yaz aylarında aşırı ısınmanın önüne geçilmesi için rüzgar doğrudan yap1 içerisine alınmak yerine belirli bir açıyla alınmıştır bununla birlikte hava yapı içerisinde dolanabilmektedir.

Çizelge 6. Binada rüzgar etkisi ve yapı ile etkileşim analizi

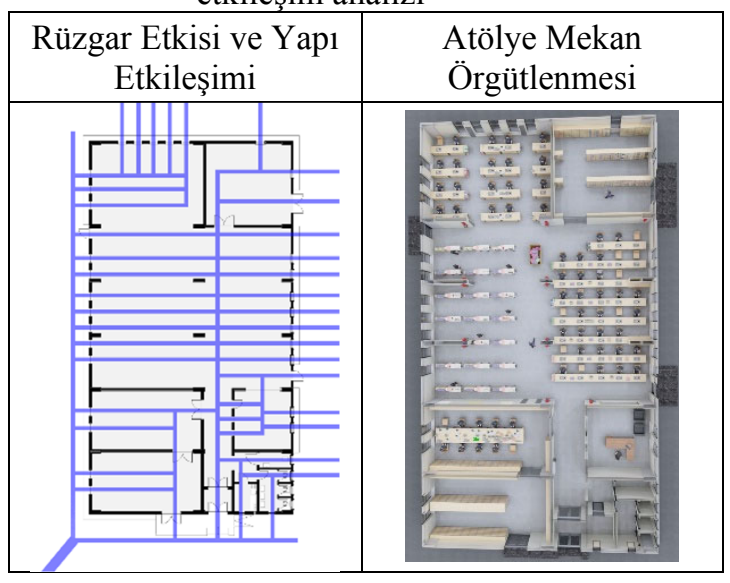

Birbiriyle iletişim içerisinde kurgulanan açıklıklar sayesinde rüzgar kontrollü bir şekilde yap1 içerisinde kesintisiz olarak dolaşabilmekte, bu sayede iç mekanların soğutulması için kullanılan enerji düşmekte yapı içerisinde hava sirkülasyonu kesintisiz olarak sağlanmış olmaktadır (Çizelge 6). Yapının kuzeyinde bulunan açıklıklar küçültülerek kuzeyden gelen rüzgarın içe alınmasının önüne geçilmiştir. Planda gösterildiği gibi güney batıya yönlendirilmiş olan pencereler ile güneye cephesi olmayan odalar da bu rüzgardan faydalanmaktadır. Yapının bulunduğu iklim kuşağından dolayı temel sorun yapının soğutulmasıdır. Akşam güneşi ise istenilen ssıl konforu oluşturulabilmektedir.

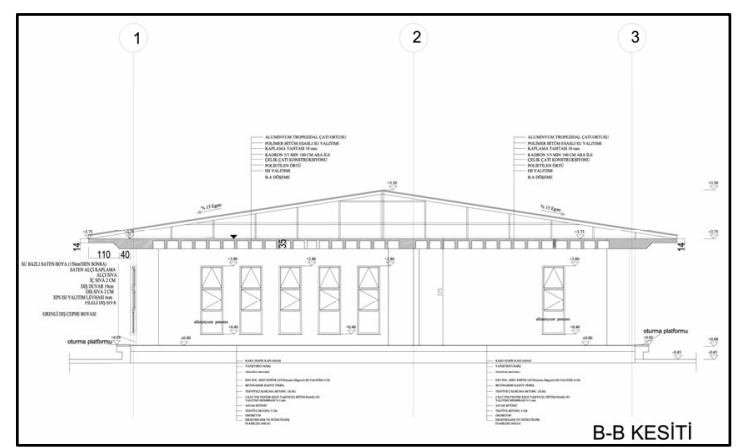

Şekil 12. Binanın enine kesiti ve 1sı iletimi [12]

Bölgede nem yoğun olduğu için gün içerisinde yap1 kabuğu aşırı ısınacak ve geceleri aşırı soğuyacaktır.

\section{YAPI FORMU VE MEKAN ÖRGÜTLENMESİ}

Atölye binasını oluşturan başlıca mekanlar işlevlerine göre atölye üretim alanı, malzeme deposu, pastal kesim, ürün deposu, şef ve yönetici ofisleri gibi gruplar halinde örgütlenmişlerdir. Ana ve destek fonksiyonlar, gürültülü-gürültüsüz mekanlar, geniş açıklıklı-dar açıklıklı mekanlar, ana girişe ve servis girişine yakın olması gereken mekanlar yönlenme özelliklerine göre konuşlandırılarak tasarlanmışlardır.

Mekanlar arasında eylemlerin etkin şekilde sürdürülmesi aktivitelerin biri birinin devamı olacak şekilde gerçekleşmesi esastır. Şekil 13'de hazırlanan ilişkiler şeması fonksiyonel ilişkileri de tanımlamaktadır. Mekanlarda gerçekleştirilecek aktiviteler için gerekli eylem alanları 
belirlenmiştir. Eylemler için gerekli donanım ve dolaşım alanlarına bağlı olarak alansal gereksinimler tespit edilmiştir. Betonarme iskelet yapım sistemi seçilerek açıklıklar kaset döşemelerle kapatılmıştır. Aydınlatma, havalandırma, güvenlik vb. sistemler asma tavan sistemi içinde çözümlenmiştir. Çizelge 7'de hazırlanan bina ihtiyaç programı ve mekan özellikleri görülmektedir. Makine ve teçhizatın değerlendirilmesi yapılarak, paketleme, ütü-pres, kesim, boya, overlok, dikiş makinası gibi ekipmanların boyut ve büyüklükleri tasarımda ele alınmıştır.

Çizelge 7. Tekstil atölyesi bina program özeti

\begin{tabular}{|c|c|c|c|}
\hline Birim & Mekan Özelliği & Kapasite & Alan $\mathrm{m}^{2}$ \\
\hline Giriş & Rüzgarlık & & $5 \mathrm{~m}^{2}$ \\
\hline Giriş Holü & $\begin{array}{l}\text { Çay ocağ } 1, \text { wc'ler } \\
\text { ile bağlantıll }\end{array}$ & & $21,70 \mathrm{~m}^{2}$ \\
\hline Çay Ocağ & \begin{tabular}{|l|} 
Hazırlama yıkama \\
ve seviş imkanlı
\end{tabular} & 2 & $5 \mathrm{~m}^{2}$ \\
\hline $\begin{array}{l}\text { WC- } \\
\text { Lavabo }\end{array}$ & $\begin{array}{l}\text { Biri engelli olmak } \\
\text { üzere dört adet }\end{array}$ & $3+1$ & $14,20 \mathrm{~m}^{2}$ \\
\hline $\begin{array}{l}\text { Atölye } \\
\text { Şefi }\end{array}$ & $\begin{array}{l}\text { Atölye üretim alanı } \\
\text { ile görsel } \\
\text { bağlantıl1, ofis } \\
\text { masa düzeninde }\end{array}$ & 1 & $26 \mathrm{~m}^{2}$ \\
\hline $\begin{array}{l}\text { Mal Kabul } \\
\text { Girişi }\end{array}$ & $\begin{array}{l}\text { Malzeme deposu, } \\
\text { pastal kesimle } \\
\text { direk bağlantıl1, } \\
\text { geniş kapılı }\end{array}$ & & $51 \mathrm{~m}^{2}$ \\
\hline $\begin{array}{l}\text { Pastal } \\
\text { Kesim }\end{array}$ & $\begin{array}{l}\text { Depo ve giriş } \\
\text { holüyle ilişsili } \\
\text { geniş kapılı }\end{array}$ & 15 & $51 \mathrm{~m}^{2}$ \\
\hline $\begin{array}{l}\text { Atölye } \\
\text { Üretim } \\
\text { Alanı }\end{array}$ & $\begin{array}{l}2 \text { adet acil çıkışlı, } \\
\text { depoyla ve atölye } \\
\text { şefi ile direk ilişkili } \\
\text { acık ve aydınlık } \\
\text { alan (Max günışığı) }\end{array}$ & 82 & $322 \mathrm{~m}^{2}$ \\
\hline $\begin{array}{l}\text { Ürün } \\
\text { Deposu }\end{array}$ & $\begin{array}{l}\text { Geniş kapılı, atölye } \\
\text { ve dış mekan } \\
\text { bağlantılı. }\end{array}$ & & $54 \mathrm{~m}^{2}$ \\
\hline $\begin{array}{l}\text { Toplam } \\
\text { Net Alan } \\
\end{array}$ & & 100 kişi & $550 \mathrm{~m}^{2}$ \\
\hline
\end{tabular}

Bu ekipmanların boyut ve büyüklükleri de çalışan güvenliğini maksimum düzeyde sağlayacak ölçütlerde tasarlanmıştır. Atölye çalışma mekanlarında mekan örgütlenmesinin daha iyi kurulabilmesi için büyük açıklık geçilerek taşıyıcı kolonların sayısı azaltılmıştır. Atölyede seçilecek olan koltuk, masa vb. donatıların çalışma ergonomisine, kullanıcıların yaş grubuna, fiziksel özelliklerine uygun olmasına dikkat edilmiştir. Mimari tasarım yoluyla enerji kazanımının arttırılması hedeflenmiştir. Bina tasarımında, mekan ve yapı bileşeni ölçeğinde 1sıtma enerjisi kazancının arttırılması için tasarım parametreleri seçilmiştir. Bina plan organizasyonu düzenlemesi, bina formunun seçilmesi ve pencerelerin düzenlenmesi bina tasarım ölceğinde düşünülen başlıca parametrelerdir (Şekil 14, 15).

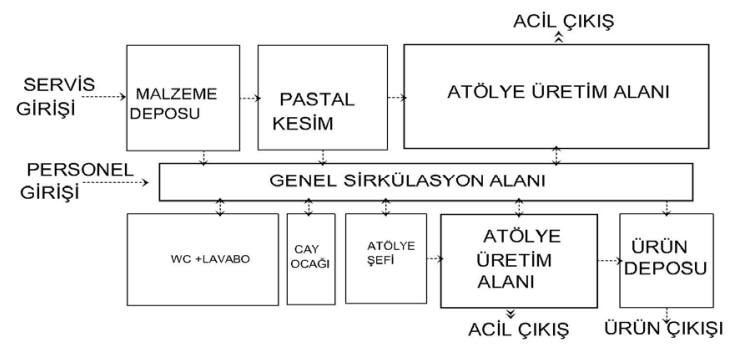

Şekil 13. Tekstil atölyesi ilişkiler şeması
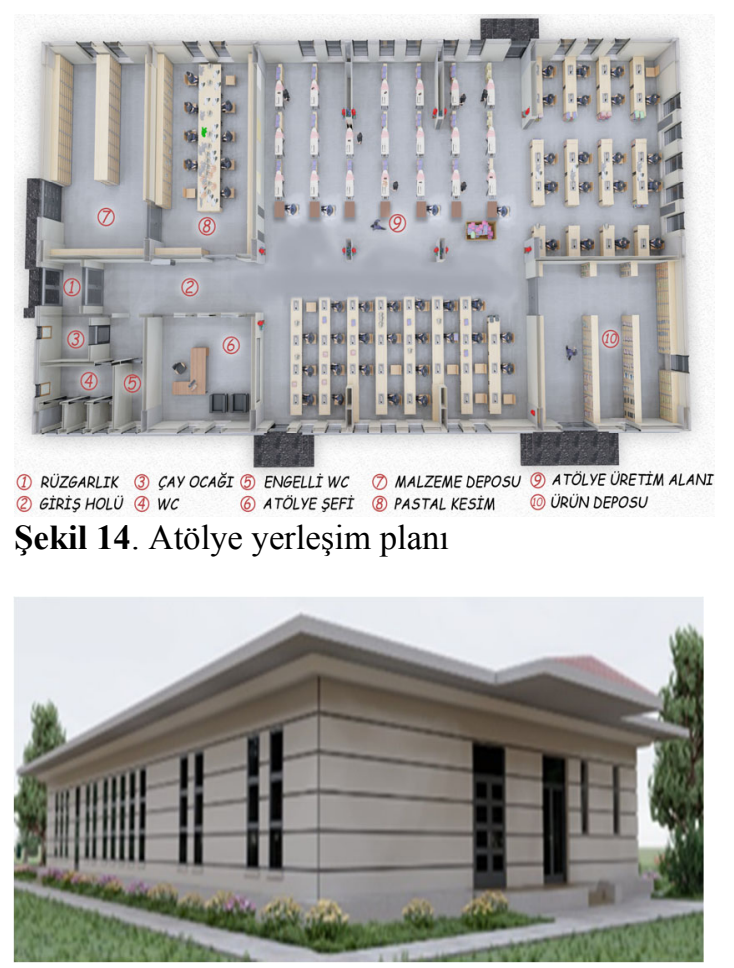

Şekil 15. Binanın güney batı görünüşü 


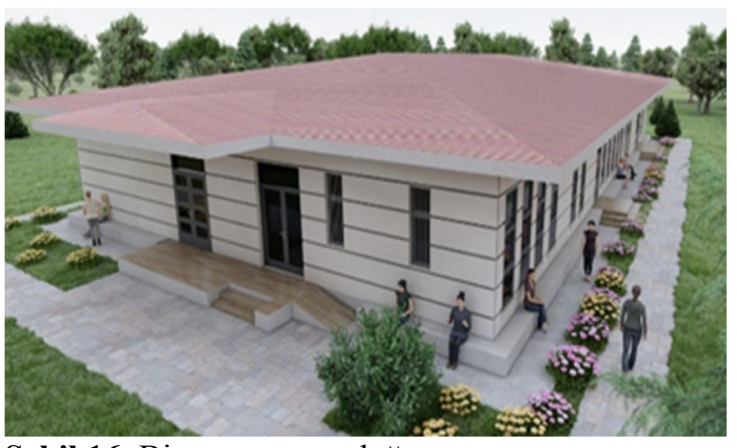

Şekil 16. Binanın güney doğu görünüşü

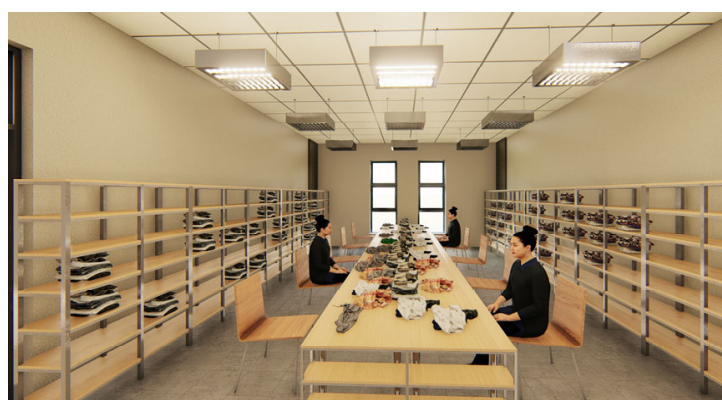

Şekil 17. Pastal kesim ve hazırlık

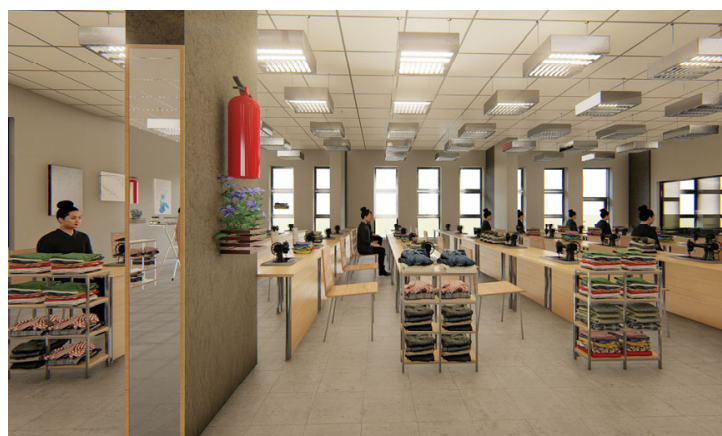

Şekil 18. Atölye üretim alanı

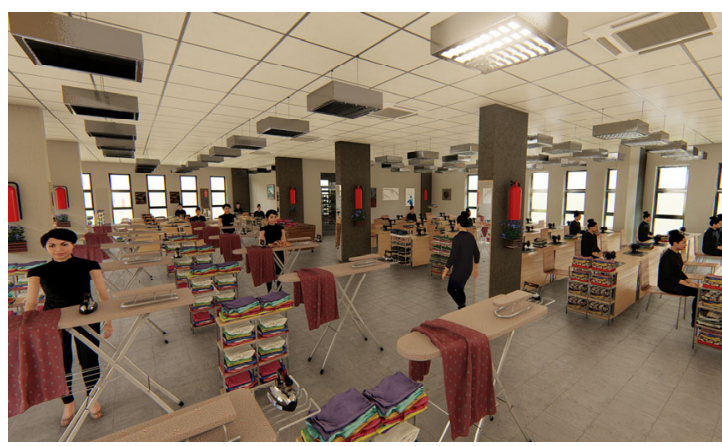

Şekil 19. Atölye üretim ve çalışma alanları

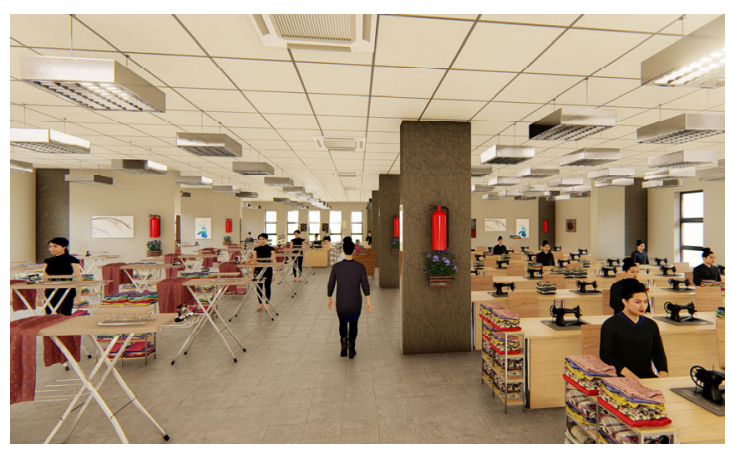

Şekil 20. Atölye iç mekanı

Mekanların plan organizasyonundaki yerleri, mekan boyutu, mekanların yönlendirilmesi, mekan tasarımı ölçeğinde değerlendirilerek kararlar verilmiştir (Şekil 14, 16-20).

Yapı bileşeni ölçeğinde iç mekanlarda hava dolaşımı, 1sı geri kazanımı için duvar ve döşeme elemanları ve pasif güneş enerjisi kullanımına ek sistemler önerilmiştir.

\section{SONUÇLAR}

$\mathrm{Bu}$ çalışmada tekstil atölyesi tasarımında ergonomi-tasarım ilişkisi ve uygulaması daha konforlu çalışma ortamları elde etmek adına ele alınmıştır. İnsan makine ilişkilerini anlamak ve sürdürülebilir bir yönetim için bu ilişkilerin doğru kurgulanması önemlidir. Tutuklu ve hükümlülerin iş organizasyonunun ve iş verimliliğinin ele alındığ 1 ergonomik faktörlerin değerlendirildiği birçok çalışma mevcuttur. Sonuç olarak bu çalışmada ergonominin temel prensiplerine dayalı yöntemler kullanılarak mekanların örgütlenmesi ve organizasyonu yapılmıştır.

Tutuklu çalışanların konfor ihtiyaçları ve çalışma verimlerinin artırıla bilmesi için örnek bir iş yurdu atölyesi tasarımı hedeflenmiş kullanıcı görüşleri de alınarak sonuçlandırılmıştır. Ceza infaz kumlarında verilen mesleki eğitim çalışmaları günümüzün ekonomik ihtiyaçları doğrultusunda düzenlenmeli, gereken önem verilerek hükümlülerin toplumsal yaşama katılımlarını sağlayacak iş atölyelerinde meslek edindirme çalışmaları artırılmalıdır. 
Atölye binalarında enerji bilinçli yenilikçi sistemler de kullanmalıdır. Bu amaçla enerji etkin yapı tasarımı mimari tasarım sürecinin planlama, programlama, ön tasarım, tasarım, uygulama, kullanım, yıkım ve yeniden planlama evrelerinin tümünü kapsayacak biçimde uzun vadede değerlendirilmelidir. Çevre sorunlarını gidermek, yapı sektöründe enerji kullanımını minimize etmek amacıyla, yapılarda yenilenebilir enerji kaynaklarının kullanılmasına yönelik çalışmaların desteklenerek enerji kullanımına yönelik ilkelerin belirlenmesine ve uygulanmasina öncelik verilmelidir. Artık işlevsellik sadece yapının kullanım amacına uygun biçimin tasarlanması değil, işlevi yerine getirirken doğayı daha az tahrip eden, çevreyle dost, enerji kullanımını denetleyen veya enerji üreten biçimlerin tasarlanmasıdır.

Mimaride güneş enerjisinden pasif olarak yararlanmak tasarım ve konstrüksiyon ile mümkündür. Yapılan atölye tasarımında güneş enerjisinden maksimum düzeyde yararlanılmaktadır. Yapıların estetik olması tek başına yeterli değildir. Enerji etkin yapı tasarımı, uzun vadede yapı maliyetini düşüren ve yapı ömrünü uzatan girişimler içermesi nedeniyle ekonomi de sağlamaktadır. $\mathrm{Bu}$ anlamda teknolojinin olanaklarını kullanarak yapı ekonomisi sağlayan ve çevreyle dost biçimler üreten mimari tercih edilmeye başlamıştır. Türkiye'nin güneşlenme yönünden ne kadar zengin olduğu düşünüldüğünde, bu konudaki maliyet ve estetik problemlerin aşılarak güneş enerjisinin kullanımının yaygınlaştırılması gerekmektedir.

Adana ve Karataş bölgesinde tekstil atölyesi için örnek teşkil eden tasarım bu konu alanında gerçekleştirilecek binalardan biridir.

\section{KAYNAKLAR}

1. Engin, N., 2012. Enerji Etkin Tasarımda Pasif İklimlendirme: Doğal Havalandırma, Tesisat Mühendisliği, 129, 62-70.

2. Özbalta, N., 2001. Güneş Enerjisi Potansiyeli ve Uygulamalar, Yerel Gündem 21 Birlikteliğinde Yenilenebilir Enerji Kaynakları, İzmir.
3. http://www.cte.adalet.gov.tr/bilgidata tip_kadin_acik.asp

4. Önal, H.İ., 1978. Cezaevlerine Halk Kütüphanesi Hizmetleri. http://www.bby. hacettepe.edu.tr/yayinlar/dosyalar/Cezaevlerine $\% 20$ halk $\% 20 \mathrm{k} \% \mathrm{C} 3 \%$ BCt $\%$ C3\%BCphanesi $\% 2$ 0hizmetleri.pdf [Erişim Tarihi: 10.10.2018].

5. CTE, 2018. Ceza ve Tevkif Evleri Genel Müdürlüğü, http://www.cte.adalet.gov.tr

6. Resmi Gazete, 2018a. Ceza ve Güvenlik Tedbirlerinin İnfazı Hakkında Kanun. http://www.resmigazete.gov.tr/eskiler/2006/04/ 20060406-1.htm

7. Sensoy, S., 2016. Climate of Turkey. Türkiye Devlet Meteoroloji Genel Müdürlüğü, http://www.mgm.gov.tr/files/enus/climateofturkey.pdf

8. https://www.izoder.org.tr/dosyalar/haberler/ Turkiye-U-degerleri-haritasi-raporu-2016Turkce.pdf

9. http://comfort.cbe.berkeley.edu/[Erişim Tarihi: 11.09.2019].

10. Kanawaty, G., Çev: Akal, Z., 1997, MPM Yayınları / ILO : 29, Ankara, 470.

11. Güner M., İlleez A.A., 2007. Konfeksiyon İşletmelerindeki Çalışma Koşullarının Tespiti ve Değerlendirilmesi, Ege Üniversitesi Araştırma Fon Saymanlığ 1 Projesi, İzmir

12. Yeğin, M., 2017. Yapılarda Performans1 Attırmak İçin Yeni Metotların Modellenerek Geliştirilmesi, Ar-Ge projesi, Çukurova Teknokent, Adana. 